\title{
ESTIMATION OF GOLD IN BIOLOGICAL FLUIDS
}

BY

\author{
THOMAS N. FRASER, HUGH CONWAY, and SIDNEY L. RAE \\ From the Gardiner Institute of Medicine, University of Glasgow, \\ and the Western Infirmary, Glasgow
}

Chrysotherapy has now become a recognized form of treatment in rheumatoid arthritis and much experimental work has been done to determine the fate of gold salts in the body. Kling and his colleagues (1939) showed that gold compounds were deposited mainly in reticulo-endothelial cells, of which synovial membrane contains a large number. They were able to detect spectrographically the presence of gold in synovial fluids, even after the administration of such a small amount of gold salt as $350 \mathrm{mg}$. According to Rosenberg (1942), gold enters almost every cell in the body shortly after injection, the greatest concentration being found in the liver, spleen, kidneys, and skin.

Block and Buchanan (1940) claimed to have devised an accurate and specific microcolorimetric method for the determination of small amounts of gold in biological fluids such as blood and urine. This method has been used extensively by these workers and their colleagues to study the metabolism of injected gold salts (Block, Buchanan, and Freyberg, 1941, 1942 ; Freyberg, Block, and Levey, 1941, 1942 ; Freyberg, 1942 ; Freyberg, Block, and Wells, 1942; Block, 1944). They found that, when intramuscular injections of myochrysine were given at weekly intervals and when the dosage was kept at a constant level $(100 \mathrm{mg}$. myochrysine, that is, $50 \mathrm{mg}$. gold) the concentration of plasma gold remained fairly constant $(0.4$ to $0.8 \mathrm{mg}$. per $100 \mathrm{ml}$.). Furthermore, during the period of administration much of the gold was retained in the body. With a weekly injection of $50 \mathrm{mg}$. of gold, the average daily excretion, mainly in the urine, was $1 \mathrm{mg}$. Thus during treatment about 80 per cent. of the injected gold remained in the body. After a course of injections gold could be recovered from the blood and urine for long periods, even up to one year.

During an investigation into the effect of BAL (2:3-dimercaptopropanol) on patients receiving myochrysine for rheumatoid arthritis, we decided to use the method of Block and Buchanan (1940) to estimate the amount of gold in blood and urine before and during BAL administration. Their technique was carried out in the strictest detail.

\section{Method}

The method devised by Block and Buchanan (1940), a modification of the technique described by Pollard (1937), depends on the use of a colour reaction produced by o-dianisidine and gold chloride in a slightly acid buffered solution, the colour being measured quantitatively in a photo-electric colorimeter. Preliminary digestion of the blood and urine with sulphuric acid and hydrogen peroxide is followed by conversion of the separated gold into gold chloride by the addition of aqua regia.

TABLE 1

DAILY RESULTS IN A PATIENT RECEIVING $100 \mathrm{mg}$. MYOCHRYSINE AT WEEKLY INTERVALS

\begin{tabular}{|c|c|c|c|}
\hline Day & $\begin{array}{l}\text { Myochrysine } \\
\text { (mg.) }\end{array}$ & $\begin{array}{l}\text { Plasma gold } \\
\text { mg./100 c.cm. }\end{array}$ & $\begin{array}{l}\text { Urinary gold } \\
\mathrm{mg} . / 24 \mathrm{hrs} .\end{array}$ \\
\hline 1 & 100 & - & - \\
\hline 2 & 一 & Nil & 0.66 \\
\hline 3 & - & Nil & 0.58 \\
\hline 4 & - & $0 \cdot 10$ & 0.80 \\
\hline 5 & - & $0 \cdot 18$ & $1 \cdot 31$ \\
\hline 6 & 一 & Nil & 0.39 \\
\hline 7 & - & $0 \cdot 20$ & 0.61 \\
\hline 8 & - & $0 \cdot 20$ & $2 \cdot 68$ \\
\hline 9 & 100 & $0 \cdot 15$ & $2 \cdot 57$ \\
\hline 10 & - & Nil & -0.50 \\
\hline 11 & - & 0.12 & $1 \cdot 39$ \\
\hline 12 & - & Nil & $0.84^{\circ}$ \\
\hline 13 & - & $0 \cdot 23$ & $1 \cdot 15$ \\
\hline 14 & - & Nil & $0 \cdot 29$ \\
\hline 15 & - & Nil & Nil \\
\hline
\end{tabular}




\section{Results}

Over 150 samples of blood and urine were taken from a series of patients with rheumatoid arthritis who were receiving injections of myochrysine, and examined quantitatively for gold content. In some instances the estimations were done daily and in others at weekly intervals. At first single observations were performed on each specimen, but it soon became apparent that the results showed great variation, even when the weekly dosage of myochrysine was kept constant. A typical example is shown in Table 1 .

It was therefore decided to control the method by estimating each specimen in duplicate or triplicate. This was done on a large number of samples of blood and urine, and we found that in most instances the results were not comparable. Table 2 shows the figures obtained in eight cases.

TABle 2

RESULTS OF TRIPLICATE ANALYSIS OF SINGLE SPECIMENS OF BLOOD AND URINE FROM EIGHT PATIENTS ON CHRYSOTHERAPY

\begin{tabular}{|c|c|c|c|}
\hline Case & $\begin{array}{c}\text { Plasma gold } \\
\text { mg./100 c.cm. }\end{array}$ & Case & $\begin{array}{l}\text { Urinary gold } \\
\text { mg. } / 24 \mathrm{hrs} .\end{array}$ \\
\hline 1 & $\begin{array}{c}\mathrm{Nil} \\
0 \cdot 22 \\
0 \cdot 50\end{array}$ & 5 & $\begin{array}{l}0 \cdot 92 \\
2 \cdot 54 \\
2 \cdot 11\end{array}$ \\
\hline 2 & $\begin{array}{c}0.23 \\
\text { Nil } \\
0.47\end{array}$ & 6 & $\begin{array}{l}0 \cdot 74 \\
1 \cdot 80 \\
4 \cdot 05\end{array}$ \\
\hline 3 & $\begin{array}{c}\text { Nil } \\
0 \cdot 30 \\
\text { Nil }\end{array}$ & 7 & $\begin{array}{l}2 \cdot 98 \\
4 \cdot 40 \\
0 \cdot 92\end{array}$ \\
\hline 4 & $\begin{array}{l}0 \cdot 47 \\
0 \cdot 22 \\
0 \cdot 10\end{array}$ & 8 & $\begin{array}{c}1 \cdot 31 \\
\mathrm{Nil} \\
0 \cdot 80\end{array}$ \\
\hline
\end{tabular}

Ampoules from the batch of myochrysine used during the investigation were analysed by the same method; the expected result was obtained on only one occasion. The estimation of known amounts of gold chloride added to both plasma and urine also gave disappointing results (Table 3). On the other hand we found, as originally described by Pollard (1937), that gold could be recovered with a considerable degree of accuracy when measured amounts of gold chloride were added to simple aqueous solution (Table 4).

\section{Discussion}

Our object in presenting this paper is to demonstrate that, in our hands, the method of Block and
TABLE 3

RECOVERY OF KNOWN AMOUNTS O' GOLD ADDED TO PLASMA AND URINE

\begin{tabular}{|c|c|c|c|}
\hline \multicolumn{2}{|c|}{ Plasma } & \multicolumn{2}{|c|}{ Urine } \\
\hline $\begin{array}{c}\text { Gold added } \\
\qquad \mu \mathrm{g} .\end{array}$ & $\begin{array}{l}\text { Gold } \\
\text { recovered } \\
\mu \mathrm{g} .\end{array}$ & $\begin{array}{c}\text { Gold added } \\
\mu \mathrm{g} .\end{array}$ & $\begin{array}{l}\text { Gold } \\
\text { recovered } \\
\mu \mathrm{g} .\end{array}$ \\
\hline $\begin{array}{l}20 \\
20 \\
20 \\
20 \\
20\end{array}$ & $\begin{array}{c}\mathrm{Nil} \\
18 \cdot 6 \\
15 \cdot 0 \\
\mathrm{Nil} \\
5 \cdot 5\end{array}$ & $\begin{array}{l}50 \\
50 \\
50 \\
50 \\
50\end{array}$ & $\begin{array}{c}\mathrm{Nil} \\
14 \cdot 3 \\
23 \cdot 2 \\
\mathrm{Nil} \\
15 \cdot 4\end{array}$ \\
\hline
\end{tabular}

TABLE 4

RECOVERY OF KNOWN AMOUNTS OF GOLD CHLORIDE (CALCULATED AS GOLD) ADDED TO SIMPLE AQUEOUS SOLUTION

\begin{tabular}{cc}
$\begin{array}{c}\text { Gold added } \\
\mu \mathrm{g} .\end{array}$ & $\begin{array}{c}\text { Gold recovered } \\
\mu \mathrm{g} .\end{array}$ \\
\hline 5 & $4 \cdot 5$ \\
10 & $10 \cdot 8$ \\
20 & $19 \cdot 2$ \\
40 & $40 \cdot 2$ \\
\hline
\end{tabular}

Buchanan (1940) for estimating gold levels in plasma and urine has yielded inaccurate results. Pollard's technique, which applies only to recovery of gold from simple aqueous solution, is eminently satisfactory, but we think that in its application to biological fluids it is far from reliable.

Macleod (1948) investigated the effect of BAL on urinary gold excretion by this method and found that the results, in the three cases studied, were very unsatisfactory as judged by estimation of duplicate samples.

Previous literature on the subject makes no mention of the anticoagulant used in the plasma estimations. Potassium oxalate was our original choice, and it was thought that this might be responsible for the erratic results of the blood levels because of the possible interaction of oxalate and gold chloride (Tukats, 1933). The substitution of heparin, however, produced no improvement.

As yet there does not appear to be an accurate method of determining the amount of gold in biological fluids and the published views on the rate of absorption of gold from the site of injection and on its elimination from the body should, therefore, be accepted with reserve. Further research on this aspect of gold therapy is both necessary and desirable. 


\section{Summary}

1. Previous work on the estimation of gold in plasma and urine is briefly reviewed.

2. An investigation of the blood and urinary gold levels, by the method of Block and Buchanan (1940), in a series of patients with rheumatoid arthritis who were receiving chrysotherapy is described. Unreliable results were obtained as judged by the estimation of duplicate and triplicate samples.

3. The opinion is expressed that there is not as yet an accurate method for estimating gold in biological fluids.

\section{REFERENCES}

Block, W. D. (1944). Annals of the Rheumatic Diseases, 4, 39.

—, and Buchanan, O. H. (1940). J. biol. Chem., 136, 379.

73, and Freyberg, R. H. (1941). J. Pharmacol., 73, 200.

(1942). Ibid., 76, 355.
Freyberg, R. H. (1942). Proc. Mayo Clin., 17, 534.

-, Block, W. D., and Levey, S. (1941). J. clin. Invest., 20, 401. Diseases, 3,77

1942). Annals of the Rheumatic , and Wells, G. S. (1942). Clinics, 1, 537.

Kling, D. H., Sashin, D., and Spanbock, J. (1939). J. Lab. clin. Med., 24, 1241.

Macleod, J. G. (1948). Annals of the Rheumatic Diseases, $7,143$.

Pollard,W. B. (1937). Analyst, 62, 597.

Rosenberg, E. F. (1942). Proc. Mayo Clin., 17, 264.

Tukats, S. (1933). Biochem. Z., 260, 143.

\section{Détermination de l'Or dans les Liquides Biologiques Résumé}

On revise brèvement les travaux précédents sur la détermination de l'or dans le plasma et dans l'urine. On décrit l'investigation du niveau de l'or dans le sang et dans l'urine par la méthode de Block et Buchanan (1940) dans une série de malades atteints d'arthrite rhumatismale et soumis à la chrysothérapie. Des résultats inconstants furent obtenus, jugeant d'après la détermination de deux ou trois échantillons similaires. On exprime l'opinion qu'une méthode exacte pour déterminer l'or dans les liquides biologiques n'existe pas encore. 